\title{
South African discourse analysis in theory and practice ${ }^{1}$
}

\author{
A B du Toit ${ }^{2}$ \\ (University of Pretoria)
}

\section{ABSTRACT}

\section{Discourse analysis in theory and practice}

Discourse analysis should not be overly ambitious, but it can be a most helpful exegetical tool if it concentrates on the argumentative flow and thematic aspects of a discourse. A refined model of South African discourse analysis is presented. The different stages in this model are discussed and illustrated by means of Philippians 3:2-11. Special attention is given to problems regarding the dividing of the text into colons.

\section{INTRODUCTORY REMARKS}

In a previous article attention was given to the birth and development of discourse analysis, both internationally and nationally ${ }^{3}$. Various factors that prevented discourse analysis from developing its full potential were discussed and some remedies suggested. It became clear that discourse analysis can be a most helpful exegetical tool if its practitioners would concentrate on what this method can do best, namely to describe the argumentative flow and determine the main theme and sub-themes of a specific discourse.

The model of discourse analysis (henceforth abbreviated as DA) presented here agrees substantially with that initiated and

\footnotetext{
1 Presented in honour of an esteemed colleague and friend who always showed a special understanding for the hermeneutical and exegetical challenges with which biblical scholars are confronted. A more extensive version of this article is due to appear in Du Toit, A B (ed.). Focusing on the Text. New Testament Hermeneutics, Exegesis and Methods. Pretoria: Protea Publishers.

2 Navorsingseenheid, Departement Nuwe Testament, Universiteit van Pretoria.
}

3 See Du Toit (2004a). 
developed by J P Louw ${ }^{4}$ and further refined by members of the New Testament Society of South Africa ${ }^{5}$.

\section{COMING TO GRIPS WITH DISCOURSE ANALYSIS}

This model of DA, which is also termed colon analysis, entails the following stages:

1. Demarcating the textual unit.

2. Subdividing the text into colons.

3. Determining thematic or structural markers.

4. Grouping the colons into larger configurations.

5. Formulating the themes of (a) the sub-units and (b) the unit as a whole.

6. Describing the unit's main communicative thrust (argumentative flow).

\subsection{Demarcating the textual unit}

A textual unit should be selected and demarcated which is long enough for a meaningful analysis, but still short enough to be readily comprehended and studied. Elsewhere I have already presented the various criteria according to which such a demarcation should be done $^{6}$. Therefore I shall not repeat them here.

\subsection{Subdividing the text into colons}

Colon analysis is not an end in itself. The biblical texts with which we are working present themselves in the form of relatively compact, cohesive stretches of language, interrupted by breaks of various length. Concomitant with these features, we are confronted with a text that is split up into verses, sub-paragraphs, paragraphs, pericopes and chapters ${ }^{7}-$ a process intended to facilitate reading and

4 Cf. especially his pioneering work in Louw (1973; 1976:117-176; 1978; 1979; 1992).

5 The author was actively involved in this process [cf. i. a. Du Toit (1974; 1977; 1979; 1980). Pelser, Du Toit, Kruger \& Roberts (1992)] and is, in particular, responsible for the theory of thematic markers which is explained and applied below. He takes full responsibility for the positions taken and examples presented in this article.

$6 \quad$ See Du Toit (2004b:65-74).

7 Also the system of providing capitals is often misleading and confusing. Cf. for example Heb 13:9-17: There seems to be no reason why a caesura followed by a capital is inserted between vv. 11 and 12, since these verses 
preaching, but which originated in later centuries and which is often not satisfactory from a linguistic perspective. What makes matters worse is that the text presented in this way tends to precondition our reading of these documents. Colon analysis not only opens up the compact stretches and relativises the breaks (verses, paragraphs, etc.), it also enables us to get a fresh and more objective perspective on the text, and to arrange/rearrange its contents in a more convincing manner. In a sense, colon analysis of biblical texts is like dismantling and reassembling an engine that has been tampered with. Sometimes it runs quite smoothly; but then again it sputters and backfires; and occasionally it even stalls. The purpose of this exercise is to see how the engine fits together, how it works, what adjustments should be made to counter the tampering and then to put the pieces together again so that the engine may function optimally. In colon analysis the biblical text is first broken down into a number of basic units, all enjoying equal syntactic status and which, for the sake of convenience, are called cola or colons ${ }^{8}$, it is then "reassembled" into larger linguistic units that, in certain instances, will endorse previous activities, putting them into a more meaningful perspective, but in others will indicate better options. At the same time, while respecting these colons and colon groupings as relatively auto-semantic entities, they should constantly be understood as being part of and determined by their relation to the macro units to which they belong.

\subsubsection{What is a colon?}

Colons are in essence syntactic units functioning on the surface of the text. They form a gateway to the semantics of the text and, to an important extent, coincide with the thought units - which are semantic concepts - contained in the text. "A colon may be regarded as essentially a thought unit, but a thought unit is not necessarily a colon” (Louw 1979, II:25).

Described in terms of traditional grammar, a colon may be either a simple or a complex sentence. "The dog chases the cat" would be such a simple sentence. A complex sentence would be:

semantically belong closely together. Why does v. 15 also begin with a capital, in contrast to other verses divided by a period? Examples of this kind abound.

8 The Greek word $k w l$ on is multivalent in the sense that it may indicate a member or part of anything, also part of a verse or an element of a sentence see LSJ s.v. However, in colon analysis it is used in a specific technical sense. 
"The dog which I saw was chasing a cat as if its entire future was at stake". The main clause of this sentence would be "The dog was chasing a cat". The subject "dog" in the main clause is qualified by the adjectival sentence "which I saw", and the main verb "was chasing" is modified by the adverbial sentence "as if its entire future was at stake". All of this would form only one colon. However, in a compound sentence, where two or more main verbs may occur, one has two or more colons, each revolving around one of these main verbs and having the same or a different subject. In the case of a compound sentence such as "I came home, ate my supper and went to bed, but Janice stayed awake for another hour”, four main verbs occur, implying that this compound sentence would consist of four colons. Every colon will contain a main verb and its concomitant subject, although the latter does not always show on the surface of the text. A command like "Smile!" will be a full colon, although the subject must be retrieved from the context.

Formulated in terms of modern linguistics, a colon is a stretch of language, consisting of a noun/noun phrase (= subject) stringed together with a verb/verb phrase (= predicate), which can function meaningfully on its own, that is, which is not embedded in a higher level hierarchy, together with all the elements that may be embedded in either the noun/noun phrase (NP) or the verb/verb phrase (VP) ${ }^{9}$. These embedded elements may be words, phrases or sentences:

9 The traditional "object" and "indirect object" being regarded as part of the verbal element or predicate. Louw (1979:24) defines the colon as follows: "A colon is syntactically a stretch of language having a matrix which consists of a nominal and a verbal element along with additions linked to these two elements of the matrix, or additions which are in turn linked to other additions." H C du Toit (1977:1) in turn says “... we could define a colon as an independent grammatical construction, consisting of a noun-phrase and a verb-phrase (together with possible embedded elements), which, in itself, is not embedded in some higher-level configuration". 


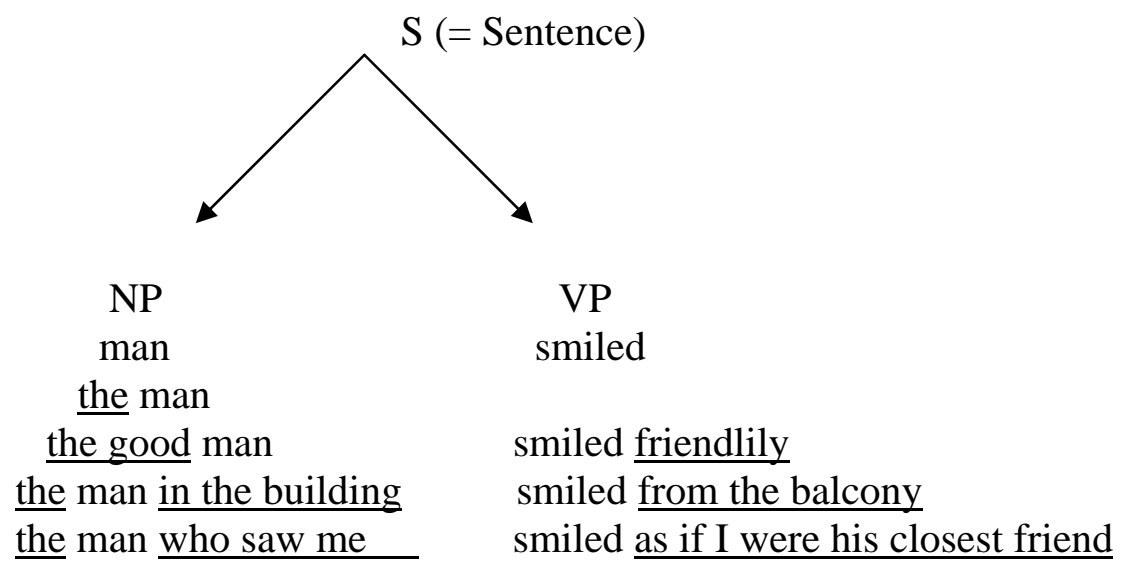

Naturally, there may be further embedments within the first level ones, etc. For example:
(a) the man
(b) who sat in the restaurant
(c) where we met yesterday

Here (b) is embedded in (a), qualifying "the man"; (c) again, is embedded in (b), qualifying "restaurant”.

This process may, theoretically, continue ad infinitum. Nouns/noun phrases embedded in the VP, like the traditional direct and indirect object, may also contain embedded elements. It should be added that, minimally, there may be only one noun/noun phrase functioning as subject of the VP, but there can be more such nouns/noun phrases connected to the same verb, for example "The Pharisees and scribes came to Jesus". In this case, we still have one colon $^{10}$.

Configurations containing more than one NP-VP combination that are not embedded in higher hierarchies will consist of two or more colons. These colons will typically be bound together by coordinate connectives like "and", "but", etcetera. For example: "Saying that, he went home" will be only one colon since "saying that" qualifies "went home”. Likewise, "after he said that, he went home", will also be one colon. On the other hand, "he said that and went home" or "he said that, but she denied it" will each contain two colons.

10 However, when two verbs are joined by connectives like "and", "but" etcetera the number of colons will increase accordingly. Vide infra. 
In dividing the Greek New Testament text into colons, one encounters specific problems, some of which may also occur in translations. We shall now address the most important ones.

1. Usually of $h\{0\{$ (who, which) functions as a relative pronoun introducing an embedded qualification, as in John 6:9:

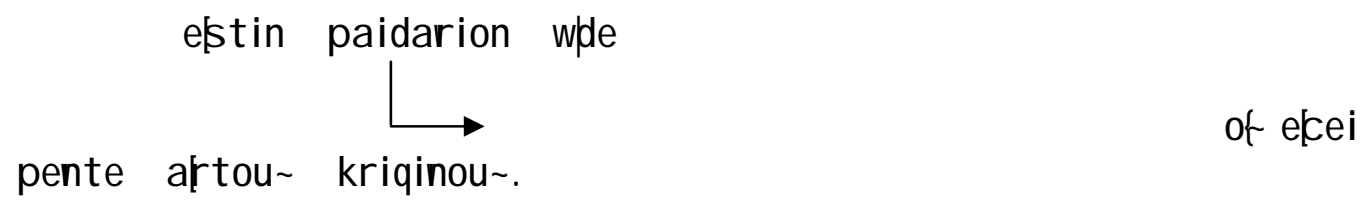

Here is a boy

five barley loaves.

who has

However, what should we do with of in Acts 7:20?

En w/kairwlegennhgh M wush" kai;hh aśteiò" tw/qew?

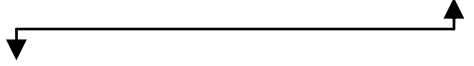

o\} ajetrafh mhǹa" trei" en tw/oikw/t ou'patrou".

It is obvious that of refers back to Moses, but its function is not in fact to qualify or identify. It rather serves as a coordinating connective, introducing the next stage of the Moses story. Without ado it can be substituted by (kai) a uf o $\forall$ or (kai;) out $0 \sim$ ("[and] he"). This implies that of no longer introduces an embedded statement, but a new colon. Acts 7:20 will therefore consist of three colons instead of two. In English these would be:

1. At that time Moses was born

2. and he was very special in the eyes of God.

3. He was nurtured for three months in his father's house.

This use of of $h\{0\{$ (together with their oblique cases) frequently occurs in the New Testament. It appears prolifically, for instance, in 1 Peter $^{11}$ and is typical of confessional material ${ }^{12}$.

2. Gav also creates problems, as is apparent in the following example:

11 Cf. for instance 1 Pet 1:3-12.

12 Phil 2:6; Col 1:15; 1 Tim 3:16 etc. 
texet ai de;uipm, kai;kal esei" to; ohoma a uf ou' Ihs ounn:

auf o," gar swsei ton Iaon auf ou apo; twn amartiwn a ut wǹ (Mt 1:21).

As indicated by the semi-colon after Jhsoun, the editors of the Greek text understood the utterance introduced by a uf 0," ga v as an independent statement, that is, as a new colon. In that case, the colon analysis would be as follows:

1. She will give birth to a son

2 and you must call him Jesus

3 for he will save his people from their sins.

One could, however, with equal right, argue that $\mathrm{g}$ a $\mathrm{r}$ introduces an embedded causal statement still belonging to the foregoing colon. The colon analysis would then be as follows:

1. She will give birth to a son

2. and you must call him Jesus

because he will save his people from their sins.

There is no clear-cut syntactic or semantic solution to this. One should, in each case, rely on your gut feeling to decide whether the ga v sentence should be treated as a new colon or not. In this case the second option may be the more appropriate, the English equivalent of $\mathrm{g}$ a v being "because" rather than "for" or "since".

The foregoing usage of gav should be distinguished from other instances in the New Testament where this particle is used as an affirmative (= "indeed"). Romans 8:17-18 illustrates this:

${ }^{17}$ eijde;t ekna, kai;kl hronomoi: kl hronomoi men qeou!' sugkl hronomoi de;

Crist ou, eiper sumpa scomen ina kai;s undoxas qwmen.

${ }^{18}$ L ogizomai gar ołi ouk akia ta; paghmata tou'nun kairou' pro," thn mell ousan doxan apokal uf ghnai eil" hma".

Romans 8:18 is clearly the beginning of an important new section, Paul now bringing some weighty new eschatological statements to the fore. Here ga v cannot be regarded as introducing an embedded causal clause since it does not motivate the immediately preceding sentence or group of sentences ${ }^{13}$. Coupled with l ogizoma i, it has a

13 Cf. also the discussion by H C du Toit (1977:7) of ga v in 1 Peter 4:15. 
strengthening function and should be understood in the sense of: "I reckon for sure” or “I am indeed certain”.

In still other cases, $\mathrm{gav}$ is, in fact, no more than a literary device serving the easy flow of the argument. A good example is its first occurrence in $\mathrm{Rm}$ 7:15:

o gar katergagomai ouj ginwskw: ouj gar o\} qeww tout o pras sw, a I I EOC \}mi s w t out o poiw:

One should not read weighty semantic information into the initial use of gav. It is a semantically neutral connective, facilitating a smooth transition. On the other hand, the second gav is clearly causal, introducing two motivating statements:

"I do not understand what I am doing; for I am not doing what I want, but what I hate - that is what I am doing."

3. Statements beginning with ina and $0 \leqslant w \sim$ occasionally present us with problems. A typical example is Matthew 2:13-15:

13 Anacwrhsantwn de; a uf wh idou; aggelo" kuriou f aimet a i kat Eohar twl J ws hf I egwn: egerqei," paravabe to; paidion kai; thn mhtera autou' kai; f eug̀e eil' Aigupton kai; ikqi ekei ew" ah eipw soi mevlei gar Hrwoth" zhtein to; paidion tou'apolesai autov ${ }^{14} 0 \mathrm{l}$ de; egerqei," parevaben to; paidion kai; thn mhtera autou' nukt o," kai;ajecwrhs en eil' Aigupton, "kai; hh ekei 'ew" th" tel eut h" Hrwou ina pl hrwah/t o; rhgen upo;K uriou dia;tou'prof htou legonto": ej A igupt ou ekavesa ton uibn mou.

In a literal English translation this passage can be divided into the following colons:

1. They (the wise men) having left, an angel of the Lord appeared to Joseph in a dream, saying:

"After getting up, you must take the child and his mother and flee to Egypt and remain there until I tell you for Herod will search for the child in order to kill him”.

2. So Joseph, after getting up, took the child and his mother with him during the night

3. and left for Egypt

4. and he stayed there until the death of Herod 
5. so that the word spoken by the Lord through his prophet was fulfilled:

"From Egypt I called my son".

Normally ina links up with the VP immediately preceding or following it, introducing an embedded clause of purpose or result. Here, however, it is impossible to connect it exclusively to "stayed" in colon 4, since it refers to the total of the foregoing section. The only remaining option is to treat it as a separate colon and to supply a missing NP-VP configuration such as "All this happened so that ... ${ }^{14}$.

4. We have a special case where two verbs are so closely connected that the action they refer to is being perceived as one (a form of hendiadys). In the utterance "Jesus answered and told them", the two verbs are so closely connected in semantic space that they should be treated as belonging to the same VP and therefore form only one colon ${ }^{15}$. Sometimes one of the two verbs comes close to being an auxiliary verb, for example in John 1:39: "Come and see". In such an instance it would be absurd to create two separate colons. A similar instance would be where an introductory egenet 0 is followed by a main verb, for example in Mark 1:9a:

Kai;egenet o ej ekeimai" tai" hmerai" hlqen Jhsou" apo; Nazaret th" Galilaia"

Egemet 0 is used pleonastically ${ }^{16}$. It does not carry any real weight as a verb. Therefore Mark 1:9a consists of only one colon.

5. Following verbs of saying and thinking we usually have a direct object in the form of what is being stated or thought. In the case of more than one such statement, it would be advisable to mark them separately by means of sub-colons, as in the following example:

1. Jesus told him:

1.1 You should love the Lord your God with all your heart and with all your soul

14 Cf. also Mt 4:14; Jn 1:22; 18:9,32; 19:24. For op w , Mt 8:17; 13:35; 23:35.

15 See also Louw (1979:20-21).

16 Cf. Blass, Debrunner, Rehkopf (1976, §44211). 
and with all your mind

1.2 This is the first and greatest commandment

1.3 And the second one which is equally important: You should love your neighbour like yourself

1.4 All the law and prophets are based on these two commandments.

(Mt 22:37-39)

The criterion for dividing the contents of such statements into subcolons is exactly the same as for colons, the logic being that these sub-colons would change into colons should the verb of saying be removed.

It should be added that the length of such a saying may be quite extensive. It can even be a long speech, such as the Sermon on the Mount, which is preceded by a verb of saying (l eg wn, following on edidasken - Mt 5:2). In such a lengthy exposition it becomes rather awkward to regard the whole as a series of sub-colons, especially since the presence of an original verbum dicendi increasingly recedes into the background. Another option could be to register a reminder at the beginning to indicate that we are dealing with a speech and then simply divide the whole into colons ${ }^{17}$.

6. It will, from time to time, be necessary to supply a verb where one is missing. As in classical Greek, the verb "to be" is often presupposed.

A prominent example is the beatitudes, for example "Blessed (are) the poor in spirit ..."

(Mt 5:3, etc.)

In the second proposition of Galatians 5:13, momon mh; [...] thn e) euqerian eif" af ormhn th/sarkiv ("only, do not [...] your freedom as/into an opportunity for the flesh"), a verb is elided. Various proposals have been made, for example (mh) ef et e ("do not regard”), ( $\mathrm{mh}$ ) ) trepete ("do not turn”), (mh) poieite (“do not make") ${ }^{18}$. A choice for any one of these verbs will not alter the basic meaning substantially.

These are but two of many examples. Usually the context suggests what verb should be supplied. In colon analysis it has become custom to bracket such a verb. However, one should

17 Cf. H C du Toit [1977:(9)-(10)].

18 Blass-Debrunner-Rehkopf (1976, §4811); Rohde (1988:228); Longenecker (1990:239); contra Schlier (1965:242). 
suppress the inclination to supply verbs wherever possible. It should only be done when it is imperative. By supplying verbs at random one may turn phrases into colons, thus giving them a stronger linguistic weight than in their original form.

7. Finally, a minor practical issue should be mentioned. Colons are often quite lengthy, with the consequence that, when written out, they may occupy several lines. For that purpose, or when the natural rhythm of a passage may require it, colons are split up into smaller units, called commata. There is no hard and fast rule for the creation of commata, other than that they should, as far as possible, form meaningful entities such as participial phrases, accusatives and infinitives, embedded clauses, etc.

\subsubsection{An example of colon divisions}

The following example shows a colon division of the Greek text of Philippians 3:2-11:

1. 2 blepet e tou," kuma"

2. blepet e tou," kakou," ejgata",

3. blepete thn katatomhn.

4 a ${ }^{3}$ hmei" gar eśmen hJperitomhy

b oijpneumat i qeou'l at reuont e"

c kai;kauc wmenoi ej cristwl Jhsou

d kai;ouk ej sarki;pepoiqote",

5. ${ }^{4}$ kaiper egw;ek wn pepoighsin kai;ej sarkiv

6a Ei[ti" dokei'a[lo" pepoiqenai ej sarkin

b egw; (dokw pepoiqemai)mall on

7a ${ }^{5}$ peritomh/(eijmi ) okt ahmero",

b ek gemou" Jsrahk,

c (ek) ful h" Beniamin,

d Ebraio" ex Ebraiwn,

e kata;nomon Farisaió",

f "kata;zhlo" diwkwn thn ekklhsian,

g kata;dikaiosumhn thn ej nomw/genomeno" a memp to".

8a ${ }^{7} \gg$ All a $1 / 4 a$ ana hh moi kerdh,

b tauta hogmai dia;t on Criston zhmian.

9a ${ }^{8}$ alla;menounge kai;hgoumai parta zhmian eihai

b dia;t o; uperevon th" gnwsew" Cristou' Jhsou't ou'kuriou mou,

10. diFon ta;part a ejhmiwghn, 
11a kai;hgoumai skubala,

b ina Criston kerdhow

c ${ }^{9}$ kai;eur eqwej a ut wl

d mh;ekwn emhn dikaios umhn thn ek nomou

e alla;thndia;pistew" Cristou;

f thn ek qeou'dikaiosumhn epi;th/pistei,

g ${ }^{10}$ t ou'gnwìai a ut on

h kai;thn dumamin th" ajast asew" aut ou'

i kai; st hn1/4koinwnian st wñ $1 / 4 p a q h m a t w n$ a uf ou,

j summorfizomeno" tw/qanatw/aut ou,'

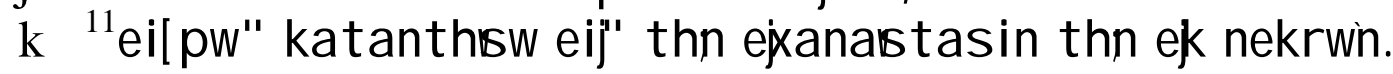

The first three colons are straightforward, each containing a toplevel NP-VP, the subject being contained within the verb. In colon 4, comata $4 \mathrm{~b}-\mathrm{d}$ are all in apposition to $4 \mathrm{a}$, qualifying $\mathrm{h}$ mei $\sim$. In colon 5 we find one of those occasions in New Testament Greek where the participle (in this case ef wn) is used instead of the finite verb ${ }^{19}$. The hmei $\sim$ of $4 \mathrm{a}-\mathrm{d}$ is now individualized. Colon 6 starts with an embedded conditional clause, followed by a main clause where the VP is elided. It is difficult to precisely determine what this VP should be. The suggestion of Lightfoot (1913:146), enclosed in brackets above, still seems to fit the context most appropriately. In $7 \mathrm{a}$ we have to supply the copulative verb eijmi. Verses $7 \mathrm{~b}-\mathrm{g}$ are all further complements of ei jmi, giving more information about Paul in his pre-Christian phase. $8 \mathrm{a}$ is an embedded clause qualifying t a ut a in 8b. di o $\mathrm{b}$ in colon 10 is another instance where the relative of does not introduce an embedded clause qualifying the foregoing noun. It serves as the introduction to a new colon in the sense of "for his sake"20. Colon 11a contains a top-level NP-VP followed by two embedded subjunctives of purpose in $11 \mathrm{~b}$ and 11c, which are alternated by an accusative and infinitive in $11 \mathrm{~g}$ and again followed by a clause of purpose in $11 \mathrm{k}$.

Since the syntax of some passages may be open to more than one interpretation, this can result in minor differences regarding their colon division. But this is of no great consequence, since the grouping of colons into larger units usually counters such minor disagreements.

See Moule (1959:179).

20 See problem 1 above. 


\subsection{Determining thematic or structural markers}

Not all practitioners of South African DA work with thematic markers. However, I have found that the process of identifying these markers $^{21}$ can be of great value - not only to divide the text into smaller, meaningful segments but also to identify its central and subthemes. All in all, this process considerably contributes towards a more informed understanding of the text as a whole.

The term "thematic" or "structural markers" refers to those surface structure words, phrases and (occasionally) even sentences, which, as a result of obvious repetition or of prominent positioning (foregrounding), point towards significant semantic slots within the discourse. As already indicated, DA starts as a syntactic exercise, but its purpose is to guide us towards the semantics of a passage. Identifying thematic markers and, by means of them, also the various prominent semantic slots of a discourse, is an important step in this direction.

The theory of thematic markers is based on the linguistic phenomenon of isotopia. In discussing this phenomenon, Link (1974:73) first refers to what he calls "rekurrierende Klasseme" that hold the text together as a meaningful unit: "In einem geschlossenen Textabschnitt ordnen sich die rekurrierenden Klasseme zu einer einheitlichen Gesamtstruktur zueinander”. These "classemes” are semantic categories functioning within the deep level of a text. "Der Text ist nur die Enfaltung dieser Struktur, die wir Isotopie ... nennen wollen.” Of the actants, or what we would prefer to call participants, he says: "In diesen Aktanten tritt die Isotopie also offen an der Oberfläche des Textes zutage” (Link 1974:75).

As a broad guideline, thematic markers can be grouped into three categories, the most prominent of these being the participants or actants. Participants can be animate entities (persons, etc.) or abstract concepts (love, flesh, sin, etc.) and can function as the subject, object or indirect object of a verb (action, event or state). Naturally, the second prominent group consists of verbs (actions/events or states [e.g. to be happy]). The third (less prominent) group refers to those markers that qualify or modify

21 Naturally, they are not always equally prominent on the surface level of the text. In certain cases the text is held together only by an underlying theme. The various ingredients of a cake recipe, for instance, are only glued together by the fact that they form part of the recipe. 
either participant roles ("the good man, etc.) or events/actions/states (she responded angrily, they were very happy, etc.). On the basic syntactic grid they usually fill what have traditionally been adjectival or adverbial slots. In the newer terminology they are called abstracts. However, it should be kept in mind that these are only broad guidelines. In practice we cannot always distinguish so neatly between these categories. For instance, specific words may refer to more than one category at the same time. A verbal form such as bl ep et e (see col. 1-3 of the above example) not only indicates an event, its second person plural ending also indicates a specific participant role ("you”). Again, a possessive pronoun such as "her" not only qualifies a noun (e.g. her name), it also refers to a specific female person. What is basically an event can also function in a participant role, as in "therefore (to) love is the fulfilment of the law" (Rm 13:10). One should therefore be flexible and open to creative adaptations, as required by a specific text. Grammatical distinctions such as word class and case may be quite helpful, but, since we are moving towards semantic categories, we shall often have to move beyond them. We must also move beyond mere words to ideas and concepts. Semantic slots are broader than mere words and phrases. They represent functional roles. This implies that various thematic markers, represented by differing words and phrases with variant meanings, may function within the same semantic slot. Within a certain context, for instance, God, Jesus Christ, the Holy Spirit and even an apostle, may function in the same positive participant slot, perhaps assisting a struggling congregation against Satan and sin - the latter functioning in an oppositional role.

In order to illustrate the idea of thematic markers and semantic slots in a very basic way, we take a look at a paragraph written by Eugene Petersen (1998:42) that has been subdivided into colons and commata. (In this case the most prominent thematic markers are abstracts $\left.^{22}\right)$ :

1. St. Paul talked about the foolishness of preaching;

2. I would like to carry on about the foolishness of congregation.

3a Of all the ways in which to engage in the enterprise of church, this has to be the most absurd -

22 In terms of modern linguistics "foolishness" is basically an abstract, since it presents a qualification or a characteristic. 
b this haphazard collection of people who somehow get assembled into pews on Sundays,

c half-heartedly sing a few songs most of them don't like,

$\mathrm{d}$ tune in and out of a sermon according to the state of their digestion and the preacher's decibels

e awkward in their commitments

f and jerky in their prayers.

Colon 3 is rather lengthy, since "has to be" in $3 a$ is the verb phrase governing everything that follows. "This" in $3 \mathrm{a}$ is used cataphorically, i.e. it points forward, $b-f$ spelling out its contents. $c-f$ are all further qualifications of "this haphazard collection of people" in b.

It is clear that the idea of "foolishness" is prominent. In 1 and 2 the semantic slot of "foolishness" is created. Other thematic markers functioning in the same semantic slot, although their semantic content differs in varying degrees, are "absurd", "haphazard", "halfheartedly", "awkward" and "jerky". In spite of the semantic variations between some of these markers, in this specific context they all combine to accentuate the notion of foolishness. Also 3d makes a contribution in this regard, but it is difficult to portray this function graphically ${ }^{23}$.

It is also important to distinguish between (more) local or horizontal markers, which cover only a segment of a passage, and continuous or vertical markers, which cover its major part. The horizontal markers assist us in grouping the colons into larger configurations (step 4) and formulating the themes of these sub-units (step 5a), while the vertical markers guide us towards determining the main theme (step 5b). Together the horizontal and the vertical markers help us towards identifying the main communicative thrust (argumentative flow) of the passage. Our next example (Phil 3:2-11) will exemplify these aspects.

23 Some would argue that "somehow" in 3b should also be marked. There will always be smaller interpretational differences in this regard, but that does not affect the broader picture, which is what DA, as defined here, should be about. In the exegetical process these smaller differences, nuances, etcetera should be reserved for the stage when a detailed analysis is done. 


\section{PHILIPPIANS 3:2-11 AS AN EXAMPLE OF DISCOURSE ANALYSIS}

In a previous exercise we have already divided Philippians 3:2-11 in colons and motivated our colon division. We shall now move to present a fuller DA of this passage.

To save space only the final result will be shown, but the process leading to it will be explained.

\section{Christians should renounce all self-righteousness and concentrate solely on Jesus Christ}

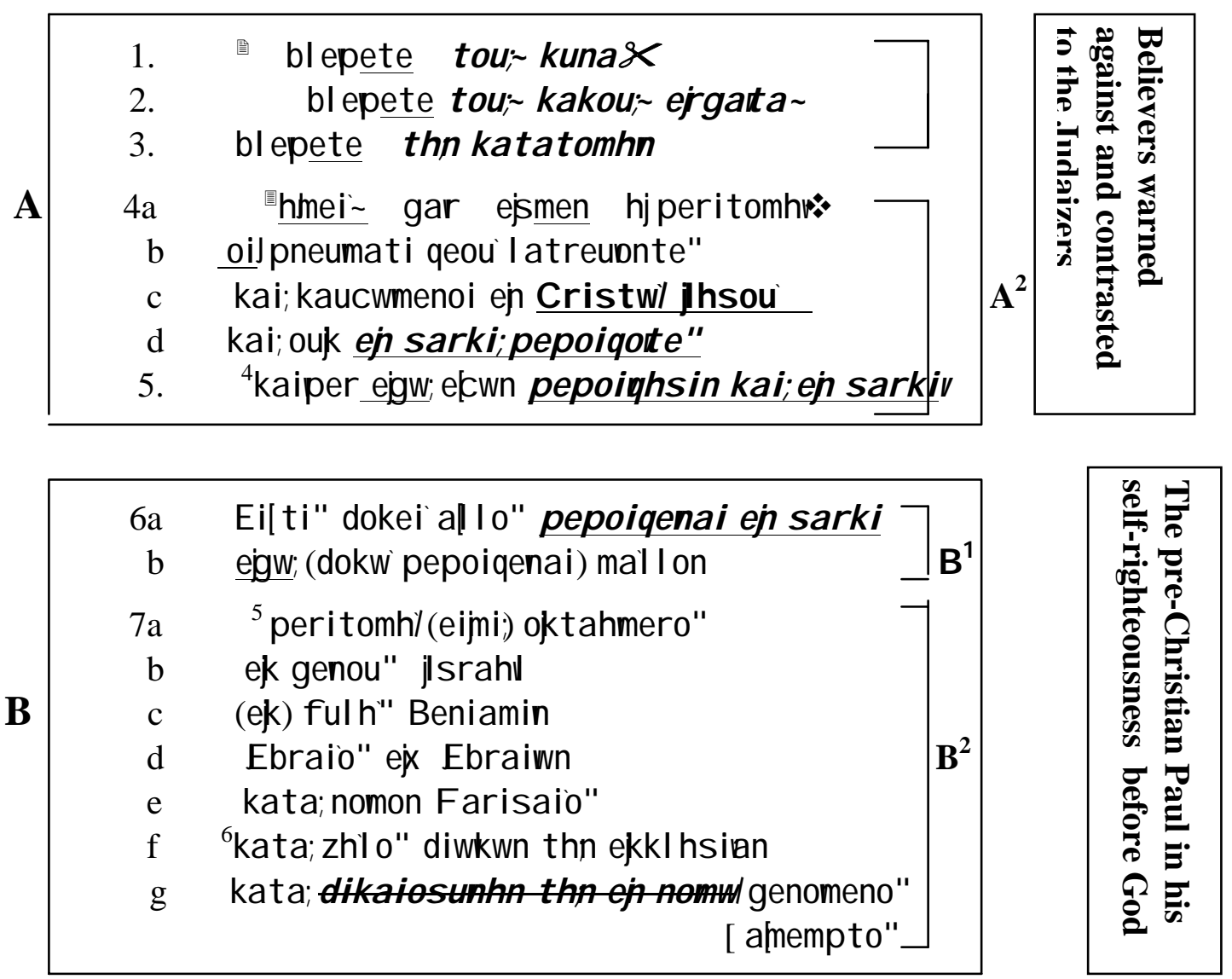




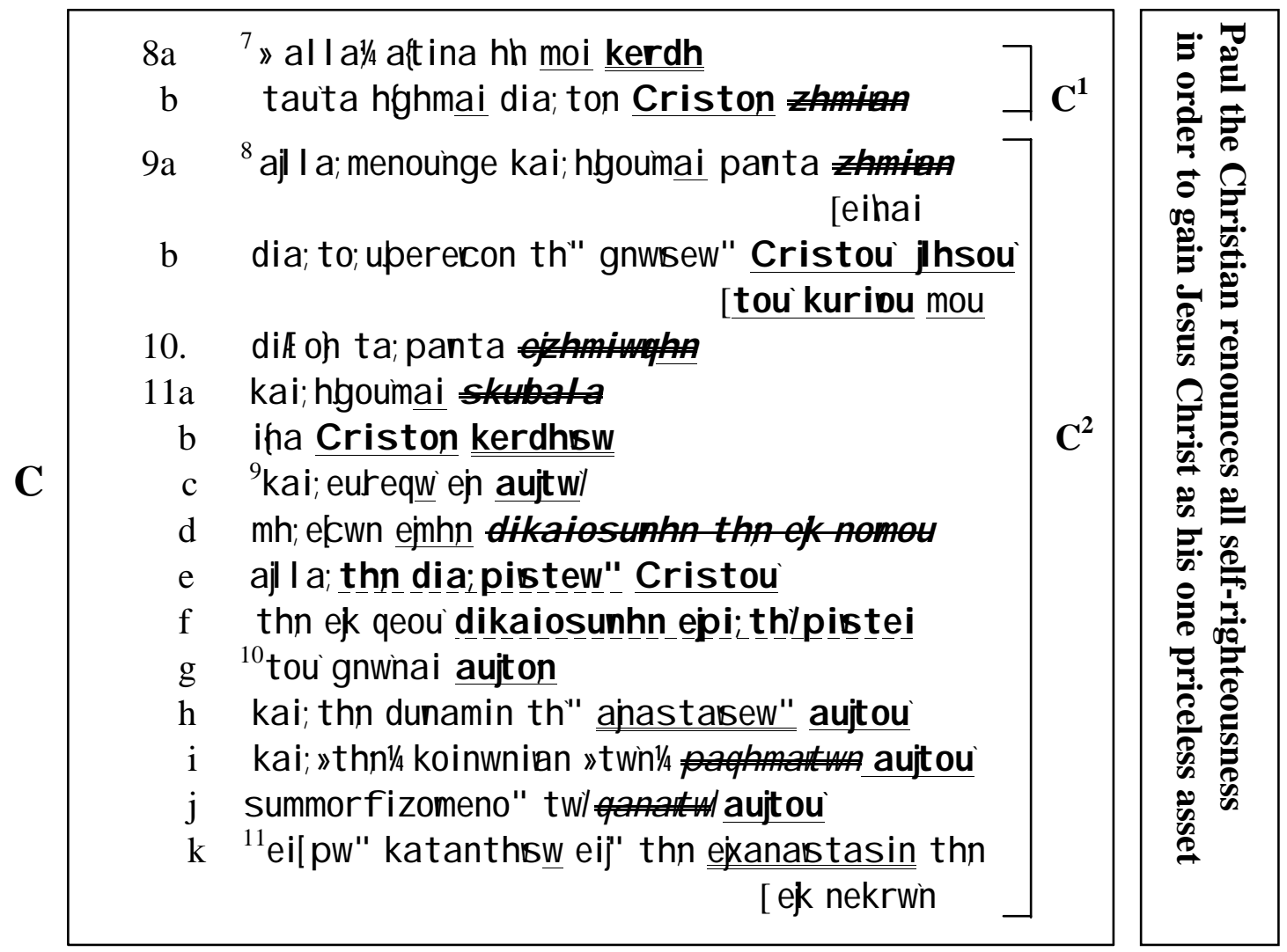

Since this sketch is more or less self-explanatory, a few remarks will suffice:

1. The most prominent participant roles in this passage are those of you/we and $\underline{\mathrm{I}}^{24}$. The passage starts with the second person plural, addressing the readers/hearers (col. 1-3). Then Paul switches to the inclusive we-form (col. 4a-d). In colon 5 a significant shift towards the first person singular occurs, which is maintained throughout (col. 5-11). Paul now becomes the role model. He describes the radical "Umwertung aller Werte" ("change in his system of values"), which took place when Jesus Christ stepped into his life, and his readers as fellow-Christians are invited to identify with him. $\underline{\text { You, we and I }}$ therefore all function together in a slot that we may call that of the Christian believers. This is clearly a vertical or continuous marker. The oppositional role is filled by the Judaizers, but they soon fade into the background (cf. col. 1-3; implicit in 4d, 6a). Jesus Christ fills a most significant participant role, but predominantly in col. 811 (cf. however 4c). Like the Judaizers, Jesus Christ is therefore a

24 In DA it is not always practical to mark all the references, especially the indirect or implied ones. For example the plural form of the three participles in colon $4 \mathrm{~b}-\mathrm{d}$ refers back to the "we" in $4 \mathrm{a}$. 
local marker. Other locally restricted markers are reliance on the flesh (4d, 5, 6a - also 6b by implication), and several antithetical pairs: gain and $\operatorname{los}^{25}$ (8ab, 9a, 10, 11ab), righteousness by faith (11ef) versus righteousness by law (7g, 11d), resurrection (11hk) and (11ij).

2. At first glance one could interpret the switch from Judaizers to believers in colon $4 \mathrm{a}$ as an indication that colon 4 signifies the beginning of a new section. However, this would be a mistake, since the ironic contrasting of kat a t omh vand perit omh glue these two participant groups together.

3. The position of colon 5 is somewhat ambiguous. It is a nexus in the sense that it still connects to colon 4 , but at the same time prepares what is to follow in B. However, since colon 6 gives the impression of a fresh beginning, it would be advisable to join colon 5 to the previous section.

4. Local markers usually help us to divide a passage into sections. However, in the case of reliance on the flesh, which appears in col. $4 d, 5$ and 6, it is clear that col. 6 should be separated from cols. $4 d$ and 5 , since it contains a generic statement which is extensively specified in $7 \mathrm{a}-\mathrm{g}^{26}$. This latter fact also indicates that colon $6-7$ form a discrete new section (= B).

5. It is obvious that the participant marker Jesus Christ, and to a lesser extent also the markers of gain and loss, glue colon 8-11 together (= C).

6. This entire passage is dominated by the opposition between dependence on the "flesh", that is relying on one's own religious achievements, and reliance on Jesus Christ. First the proponents of the first position come into view, the readers being warned against

25 In colons 7b and 8a hgeoma $\mathrm{i}+\mathrm{zhmian}$ is used, which, in terms of word classes, is a verb followed by an abstract noun, while in colon 9 the verb H $\mathrm{m}_{\mathrm{O}} \mathrm{O}(\square *$ appears, filling the same semantic slot. All three occurrences express Paul's current negative evaluation of what was previously all-important to him. In this type of exercise, where we are moving into semantics, we should not be kept hostage by grammatical categories, but think in terms of broad semantic slots. A drastic word such as s kubal a (col. 11a) functions in the same manner. In a climactic way, it expresses the "new" Paul's negative judgment on the achievements of the $s$ a $r x$.

26 This underlines that thematic markers as a criterion for dividing the text into smaller units, should always be applied most context-sensitively. 
them in vilifying terms (section $\mathrm{A}^{1}$ ). In $\mathrm{A}^{2}$ the Christians are brought on stage. In sharp contrast to the false teachers, they rely on Jesus Christ and not on the $s$ a $\mathbf{x}$. Paul is thereupon presented as role model for his readers:

The pre-Christian Paul (section B) is set off against Paul the Christian (section C). $\mathrm{B}^{1}$ is a generic statement, which is specified in $B^{2}$. The thematic pronouncement in $C^{1}$ is further amplified in $C^{2}$, the latter being a passionate statement, mapping out the very heart of Christian belief and functioning, on the rhetorical level, as a strong incentive to follow in the footsteps of Paul and remain steadfast in the Christian faith.

\section{EPILOGUE}

The example of DA presented above deals with a relatively short stretch of text. However, the same guidelines will apply for much longer passages. DA is certainly not an Alladin's lamp that will solve all exegetical problems. It is also not the exegetical method. However, as a preparatory mechanism to open up the main contours of a given text, to disclose its inner development and its main and sub-themes it has many advantages. The caveat would be that it should be practiced in a flexible and creative manner and with great sensitivity for the context. Given these important advantages, it is a major scientific set-back that the enthusiasm for this method seems to have waned lately.

\section{Consulted literature}

Blass, F A, Debrunner, A \& Rehkopf, F 1976. Grammatik des neutestamentlichen Griechisch. 14. Aufl. Göttingen: Vandenhoeck \& Ruprecht.

Du Toit, A B 1974. The Significance of discourse analysis for Bible interpretation and translating. Neotestamentica 8:54-79.

-, 1977. Analysis of the structure of Mt 4:23-5:48. Neotestamentica 11:32-47; Addendum 8-11.

-, 1979. Dikaiosyne in Röm 6. Beobachtungen zur ethischen Dimension der paulinischen Gerechtigkeitsauffassung. ZThK 76:261-291.

-. 1980. Die praktyk van die eksegese in die lig van nuwere wetenskaplike ontwikkeling, in Departemente Nuwe Testament en Grieks (ed.), Die Nuwe Testament Vandag. Pretoria: Universiteit van Pretoria, 199-235.

-, 2004a. Het diskoersanalise 'n toekoms? HTS 60, 207-220.

-, 2004b. New Testament Exegesis in Theory and Practice: The Various Stages of the Exegetical Programme. Acta Theologica 24, 64-90. 
Du Toit, H C 1977. What is a colon? Neotestamentica 11 Addendum:(1)-(10).

Liddell, H J, R Scott \& H S Jones 1996. A Greek-English lexicon. $9^{\text {th }}$ ed. with rev. suppl. Oxford: Clarendon.

Lightfoot, J B 1913. Saint Paul's Epistle to the Philippians. London: Macmillan.

Link, J 1974. Literaturwissenschaftliche Grundbegriffe. Eine programmatische Einführung auf strukturalistischer Basis. UTB 305. 2. Aufl. München: Wilhelm Fink.

Longenecker, R N 1990. Galatians. WBC 41. Dallas: Word Books.

Louw, J P 1973. Discourse analysis and the Greek New Testament. BT 24:101118.

-, 1976. Semantiek van Nuwe Testamentiese Grieks. Pretoria: Beta Drukkers.

-, 1978. 'n Semantiese struktuuranalise van Romeine. Vol. I. Pretoria: Universiteit van Pretoria.

-, 1979. A semantic discourse analysis of Romans. Vol. 2. Pretoria: University of Pretoria.

-, 1992. Reading a text as discourse, in D A Black (ed). Linguistics and New Testament interpretation: Essays on discourse analysis. Nashville: Broadman, 17-30.

Moule, C F D 1959. An Idiom-Book of New Testament Greek. $2^{\text {nd }}$ ed. Cambridge: Cambridge University Press.

Pelser, G M M, Du Toit, A B, Kruger, M A \& Roberts, J H 1992. Discourse analysis of Galatians. Neotestamentica 26, Addendum.

Peterson, E H 1998. Living the message. London: Marshall Pickering.

Rohde, J 1988. Der Brief des Paulus an die Galater. THKNT 9. Berlin: Evangelische Verlagsanstalt.

Schlier, H 1965. Der Brief an die Galater. 4. Aufl. der Neubearbeitung. KEK. Göttingen: Vandenhoeck \& Ruprecht. 